\title{
Review \\ Desalination Technology in South Korea: A Comprehensive Review of Technology Trends and Future Outlook
}

\author{
Jongkwan Park ${ }^{1}$ and Sungyun Lee ${ }^{2,3, *}$
}

1 School of Civil, Environmental and Chemical Engineering, Changwon National University, 20 Changwondaehak-ro, Changwon-si 51140, Korea; jkpark2019@changwon.ac.kr

2 Department of Civil Environmental Engineering, School of Disaster Prevention and Environmental Engineering, Kyungpook National University, 2559 Gyeongsang-daero, Sangju-si 37224, Korea

3 Department of Advanced Science and Technology Convergence, Kyungpook National University, 2559 Gyeongsang-daero, Sangju-si 37224, Korea

* Correspondence: sungyunlee@knu.ac.kr

check for updates

Citation: Park, J.; Lee, S. Desalination Technology in South Korea: A

Comprehensive Review of

Technology Trends and Future

Outlook. Membranes 2022, 12, 204.

https://doi.org/10.3390/

membranes12020204

Academic Editor: Hosik Park

Received: 9 January 2022

Accepted: 6 February 2022

Published: 9 February 2022

Publisher's Note: MDPI stays neutral with regard to jurisdictional claims in published maps and institutional affiliations.

Copyright: (C) 2022 by the authors. Licensee MDPI, Basel, Switzerland. This article is an open access article distributed under the terms and conditions of the Creative Commons Attribution (CC BY) license (https:// creativecommons.org/licenses/by/ $4.0 /)$.

\begin{abstract}
Due to advances in desalination technology, desalination has been considered as a practical method to meet the increasing global fresh water demand. This paper explores the status of the desalination industry and research work in South Korea. Desalination plant designs, statistics, and the roadmap for desalination research were analyzed. To reduce energy consumption in desalination, seawater reverse osmosis (SWRO) has been intensively investigated. Recently, alternative desalination technologies, including forward osmosis, pressure-retarded osmosis, membrane distillation, capacitive deionization, renewable-energy-powered desalination, and desalination batteries have also been actively studied. Related major consortium-based desalination research projects and their pilot plants suggest insights into lowering the energy consumption of desalination and mitigation of the environmental impact of SWRO brine as well. Finally, considerations concerning further development are suggested based on the current status of desalination technology in South Korea.
\end{abstract}

Keywords: seawater desalination; reverse osmosis; industry; research; alternative technology; energy; South Korea

\section{Introduction}

Although there is enough fresh water to meet demands at the global level on an annual basis, spatial and temporal variations of water demand and availability lead to water shortage problems in several parts of the world [1]. Presently, almost one-half of the global population, 3.6 billion people or $47 \%$, faces water scarcity in at least one month of the year. This number is predicted to rise to $57 \%$ of the global population by 2050 [2]. In response to steadily increasing water demand due to population growth, urbanization, and increased industrial and agricultural activities, seawater desalination has received the most attention as a viable option to address shortages and meet demand. Accordingly, there has been rapid growth in the desalination market, with an annual growth rate of almost $9 \%$ in 1990-2018 [3].

Before 2000, when thermal desalination was the main technology in the seawater desalination market, South Korean companies occupied a large portion of the seawater desalination market. However, government support for research and development on seawater reverse osmosis (SWRO) technologies was necessary to maintain the market share, as desalination was dominated by reverse osmosis (RO) technology in the 2000s. After the South Korean government selected seawater desalination technology as one of the top 10 priority research and development (R\&D) projects (Value Creator 10) in 2006, desalination research has been extensively investigated in South Korea [4].

In this review article, we focused on innovations in and evolution of desalination technology in South Korea. This review aims to share the history of desalination technology 
in South Korea and provide insights into the development direction of the desalination industry and its research targets. Along with major global trends, the current status of the desalination industry and relevant major desalination research projects in South Korea are introduced. Reviewing the desalination technology in South Korea offers information for understanding industrial needs and a basis for further desalination research.

\section{Fresh Water Resources and the Desalination Industry in South Korea}

\subsection{Fresh Water Resources and Desalination Facilities in South Korea}

South Korea is located in a relatively wet region. The total amount of water resources in South Korea is 132.3 billion $\mathrm{m}^{3}$ /year (2015), and the average annual precipitation in South Korea is $1277 \mathrm{~mm}$ (1978-2007), 1.6 times higher than the global average. However, due to the high population density, the annual precipitation per capita is $2629 \mathrm{~m}^{3}$ per year, only approximately $1 / 6$ of the global average [5]. Moreover, the seasonal distribution of precipitation in South Korea is not uniform. Annual precipitation in the spring is only approximately $15 \%$, while $40-60 \%$ of the annual total is concentrated in the summer from June to August. Most of the precipitation in winter is due to snowfall, except for the southern coastal regions, and the amount of annual precipitation in winter is 5-10\% [6]. Unfortunately, these spatial and temporal deviations of available water by season are expected to become even greater due to the ever-intensifying effects of climate change and the occurrence and concentration of extreme rainfall [7].

Recently, temporal water shortage issues during the dry season have triggered the consideration of seawater desalination as a solution for a stable water supply in South Korea. For example, in 2015, Chungcheongnam-do, located in the midwestern part of South Korea, suffered severe water scarcity. To solve this problem, in 2021, the South Korean government decided to build a $100,000 \mathrm{~m}^{3}$ / day SWRO desalination plant to supply water resources for a nearby industrial cluster [8].

In South Korea, medium-sized (5000-60,000 m³ /day) RO desalination facilities were first built in the late 1980s to supply industrial water [8,9]. Table 1 lists representative RO desalination plants in South Korea. Most of the RO desalination facilities are brackish water desalination plants; the first seawater $\mathrm{RO}$ desalination plant for industrial water production was constructed in 2014. Because the water shortage problem has not been serious in most areas of South Korea, small-scale $\left(<5000 \mathrm{~m}^{3} /\right.$ day $) \mathrm{RO}$ desalination facilities for municipal water have so far been installed only in islands. As of 2014, there are 109 seawater RO desalination facilities on islands of South Korea, with a total facility capacity of $8333 \mathrm{~m}^{3}$ /day [10]. Ninety-seven percent of the RO desalination facilities on islands have capacities of less than $500 \mathrm{~m}^{3} /$ day (Table 2). Because these small-scale desalination plants are located on remote small islands, proper operation and maintenance (O\&M) by expert operators is difficult. As a result, some small-scale desalination plants have been closed due to O\&M issues [11]. Therefore, automated O\&M devices or remotecontrol systems should be applied for effective management. 
Table 1. Representative RO desalination facilities in South Korea.

\begin{tabular}{ccccc}
\hline Plant Location & Capacity $\left(\mathbf{m}^{\mathbf{3}} / \mathbf{d a y}\right)$ & Feed Water Type & 1st Year of Production & Purpose \\
\hline Seosan & 16,000 & brackish water & 1988 & industrial water \\
\hline Seosan & 25,000 & brackish water & 1990 & industrial water \\
\hline Seosan & 84,000 & brackish water & 1991 & industrial water \\
\hline Dangjin & 4500 & brackish water & 1997 & industrial water \\
\hline Dangjin & 182,000 & brackish water & 2009 & industrial water \\
\hline Daesan & 119,000 & brackish water & 2012 & industrial water \\
\hline Gwangyang & 30,000 & seawater & 2014 & industrial water \\
\hline Samcheok & 2400 & seawater & 2017 & power plant \\
\hline Uljin & 10,000 & seawater & 2020 & power plant \\
\hline Daesan & 100,000 & seawater & industrial water \\
\hline
\end{tabular}

Table 2. Capacity of seawater RO desalination facilities for municipal water on islands of South Korea.

\begin{tabular}{cccl}
\hline Capacity $\left(\mathbf{m}^{\mathbf{3}}\right.$ /day) & Number of Facilities & Percentage (\%) & Purpose \\
\hline $10-49$ & 60 & 55.0 & municipal water \\
\hline $50-99$ & 29 & 26.6 & municipal water \\
\hline $100-499$ & 17 & 15.6 & municipal water \\
\hline $500-1000$ & 3 & 2.8 & municipal water \\
\hline
\end{tabular}

\subsection{Overview of Desalination Technology Trends and the Desalination Industry in South Korea}

Generally, desalination technologies can be classified into three main categories: evaporation and condensation, membrane process, or crystallization. Figure 1 shows current desalination technologies, including new technologies such as forward osmosis (FO), membrane distillation (MD), and capacitive deionization (CDI) [12,13]. Evaporation technologies began operation during the 1950s and had been the primary technology until 2000 [14]. However, tremendous improvements in RO membrane technology and energy cost increases in the last years have induced a primary desalination technology switch from thermal processes to membrane-based desalination [15]. Currently, the specific energy consumption (SEC) of RO seawater desalination, $3.5-4.5 \mathrm{kWh} / \mathrm{m}^{3}[16]$, is significantly lower than that of thermal desalination technology such as multi-stage flash (MSF; 13.5-25.5 kWh $/ \mathrm{m}^{3}$ ) and multi-effect distillation (MED; 6.5-11 kWh $/ \mathrm{m}^{3}$ ) [13]. As a result, RO desalination (51\% of new seawater desalination capacity in 2001) increased to $75 \%$ in 2003 and has continued to increase ever since [14,17].

A representative South Korean desalination plant supplier is Doosan Heavy Industries \& Construction (Changwon, Korea). Doosan Heavy is a global leading seawater desalination plant supplier, occupied fifth place for desalination capacity contracted from 2010 to 2021 [18]. Doosan Heavy was mainly focused on MSF and MED desalination, but to increase its market share in the RO technology-oriented seawater desalination market, they participated in a South Korean government R\&D program for RO technology from 2007 to 2012. Doosan Heavy constructed the world's largest desalination plant, Ras Al Khair desalination plant, with a capacity of 1,036,000 $\mathrm{m}^{3}$ /day in 2014 (MSF 727,130 $\mathrm{m}^{3} /$ day and $\mathrm{RO} 309,360 \mathrm{~m}^{3}$ /day) [19]. GS Engineering \& Construction (GS E\&C) (Seoul, Korea) is also one of the leading companies in the desalination business. In 2012, GS E\&C entered the desalination business in earnest by acquiring Inima OHL, an RO desalination plant supplier in Spain [20]. The company ranked 45th among the world's 50 largest waterrelated companies, and at the end of 2020, GS Inima won the desalination project with about 2.1 billion USD in Oman [21]. Engineering, procurement, and construction (EPC) companies such as Hanwha E\&C (Seoul, Korea) and Daewoo E\&C (Seoul, Korea) have 
also participated in national research projects (KORAE, 2016-2020) to develop seawater desalination technology [22].

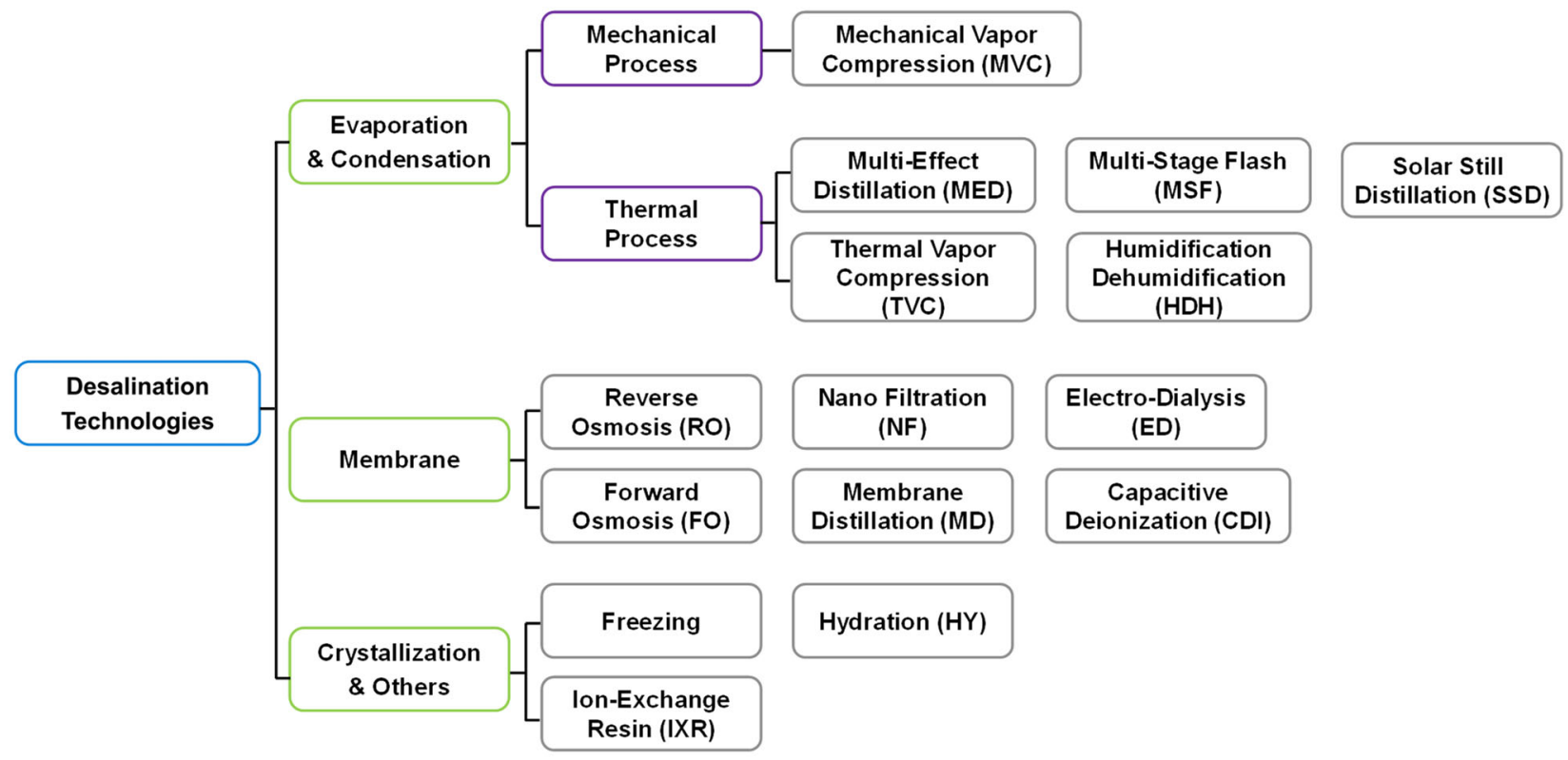

Figure 1. Categories of desalination technologies.

Because the water shortage problem in South Korea has not been serious, South Korean companies are paying more attention to the global desalination market. The global water desalination equipment market size was estimated at 13.12 billion USD in 2020 and is expected to expand at a compound annual growth rate of 7.1\% from 2020 to 2028 [23].

\section{Status of Desalination Research in South Korea}

\subsection{Roadmap of Desalination Research in South Korea}

Research publication data were collected from the Scopus database using the search term desalination for the years from 2000 to 2020 [24]. By 2020, there were 26,617 global publications, of which 1447 were from South Korea, accounting for 5.4\%. According to a recent bibliometric study, the number of desalination publications from South Korea ranks fourth in the world after China, the United States, and India [25]. Figure 2 shows the evolution of annual publications related to desalination worldwide and from South Korea between 2000 and 2020. The annual publications sharply increased in 2009 from 20 to more than 80 and reached its maximum of 163 in 2013. Since then, the publication numbers have fluctuated but maintained higher than 100. However, the publication percentages from South Korea have shown a decreasing trend since 2013, from 8.4\% to 4.5\% in 2020.

The top 20 keywords in desalination publications from South Korea are listed in Table 3. The top 10 keywords were as follows: membrane, seawater, reverse osmosis, water filtration, water treatment, fouling, osmosis, wastewater treatment, electrode, and energy efficiency. Most of the top 10 keywords are interpreted as related to $\mathrm{RO}$ technology, reflecting the recent RO-oriented market. And electrode, the ninth-ranked keyword, is considered to be related to capacitive deionization technology. The keywords ranked 11th to 20th include capacitive deionization, membrane distillation, and forward osmosis, which are alternative desalination technologies, showing the trend of desalination research in South Korea toward low-energy desalination. 


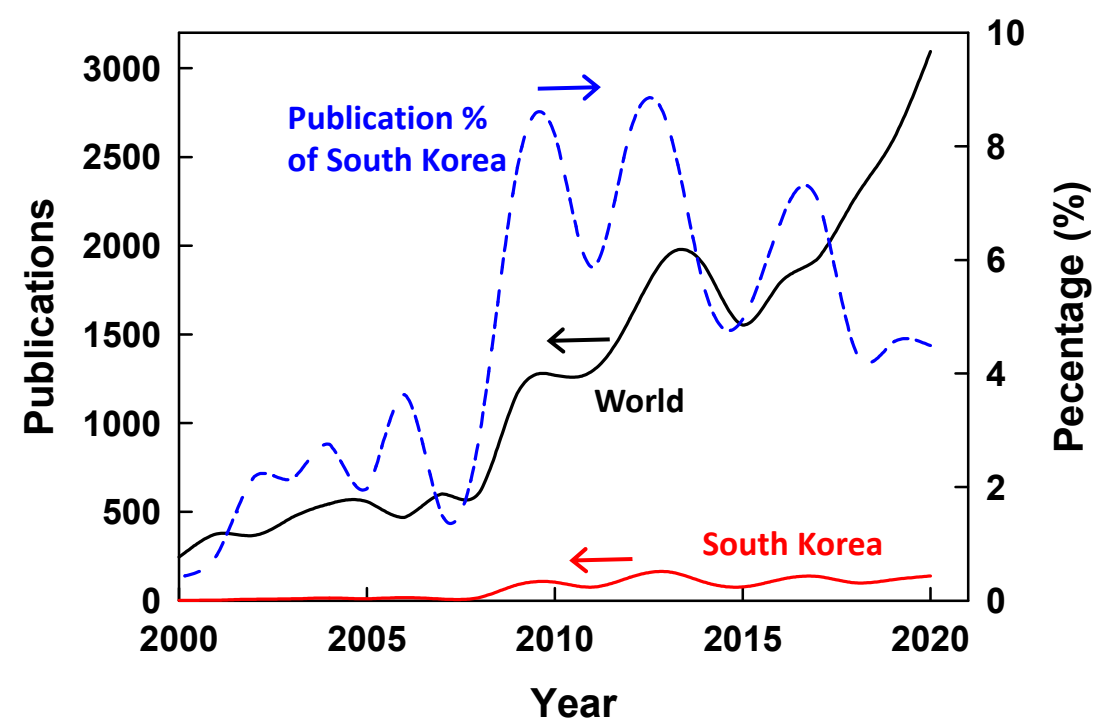

Figure 2. Trends of scientific publications related to desalination globally and from South Korea.

Table 3. Top 20 keywords for desalination research in South Korea.

\begin{tabular}{|c|c|c|}
\hline Rank & Keywords & Number \\
\hline 1 & membrane, membranes, membrane technology & 569 \\
\hline 2 & seawater, seawater desalination, sea water & 522 \\
\hline 3 & reverse osmosis, seawater reverse osmosis, RO membrane, reverse osmosis desalination & 377 \\
\hline 4 & water filtration, filtration & 377 \\
\hline 5 & water treatment, water purification, purification & 275 \\
\hline 6 & fouling, membrane fouling, fouling control & 226 \\
\hline 7 & osmosis & 182 \\
\hline 8 & wastewater treatment, wastewater, wastewater reclamation, waste water management & 162 \\
\hline 9 & electrode, electrochemical electrode & 159 \\
\hline 10 & energy efficiency, energy consumption, specific energy consumption & 152 \\
\hline 11 & capacitive deionization, membrane capacitive deionization & 150 \\
\hline 12 & distillation & 148 \\
\hline 13 & water, water supply & 143 \\
\hline 14 & sodium chloride & 119 \\
\hline 15 & forward osmosis & 115 \\
\hline 16 & membrane distillation, direct contact membrane distillation & 115 \\
\hline 17 & energy utilization & 105 \\
\hline 18 & concentration & 94 \\
\hline 19 & polarization, concentration polarization & 93 \\
\hline 20 & biofouling, biofilm & 89 \\
\hline
\end{tabular}

Major desalination R\&D projects in South Korea were analyzed using the National Science and Technology Information Service of South Korea (NTIS) databases [22]. The databases were searched using the keyword "desalination" and filtered for research funding of 100 million won (KRW)/year ( $\approx 85,000 \mathrm{USD} /$ year) or more by 2021 . According to the databases, 695 desalination research projects have been conducted since 2002. Figure 3 illustrates the major consortium-based desalination research projects in South Korea. Excellent South Korean universities, national research institutes, and major companies participated in these consortium-based research projects. As shown, the major desalination research projects can be divided into two categories, i.e., conventional RO-based desalination and alternative desalination, including FO, MD, pressure-retarded osmosis (PRO), CDI, and desalination battery. Seawater desalination research has been booming since the Center for Seawater Desalination Plant (CSDP), funded by the South Korean government, was established in 2006. After the seawater engineering and architecture of high-efficiency RO (SEAHERO) R\&D project (2007-2012) was launched by the CSDP for the development 
of SWRO plant technologies, desalination research projects based on new alternative desalination technologies were initiated between 2009 and 2014. Although these alternative desalination research projects have shown technical feasibility using pilot-scale tests, they have not yet developed into actual large-scale $\left(>60,000 \mathrm{~m}^{3} /\right.$ day) desalination plants. New research projects based on $\mathrm{RO}$ desalination technology with high potential for practical use have been carried out since 2016. The detailed status of each desalination technology is highlighted in what follows.

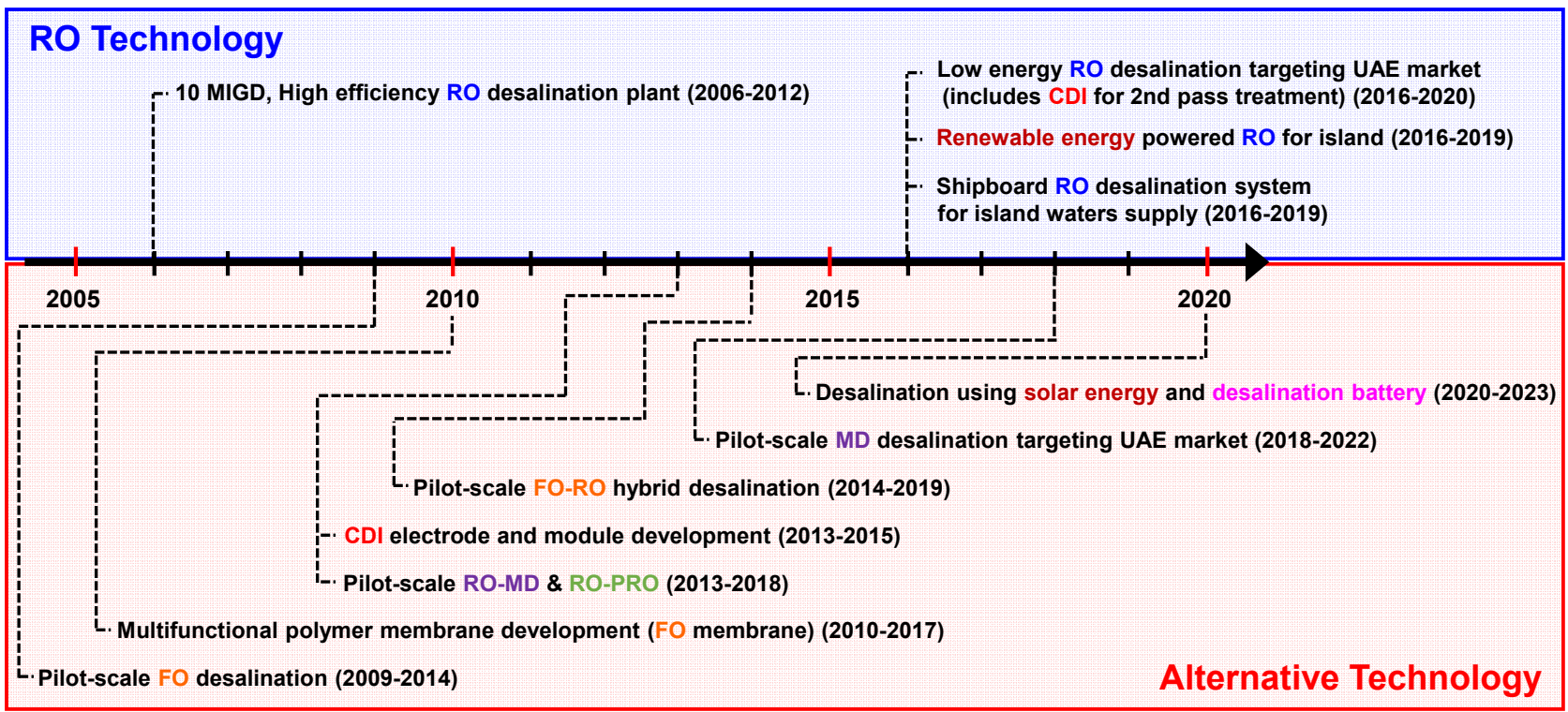

Figure 3. The milestones of major desalination research in South Korea.

\subsection{Reverse Osmosis}

With the development of energy recovery devices (ERD) in the 1990s, the SEC of SWRO reduced from $20 \mathrm{kWh} / \mathrm{m}^{3}$ to $2-5 \mathrm{kWh} / \mathrm{m}^{3}$ [26,27], making it an energy-efficient system compared to thermal desalination technologies. In addition, the continuous innovation and improvement of SWRO membranes and plant technologies led to the steady growth in both the number and capacity of RO plants. Since 2000, almost all new desalination plants with a production capacity of over $100,000 \mathrm{~m}^{3}$ /day worldwide were SWRO desalination plants [17]. The current production of desalinated water from SWRO is 65.5 million $\mathrm{m}^{3} /$ day, accounting for $69 \%$ of the desalinated water production [27].

The three main components in SWRO processes are RO membranes, high-pressure pumps, and the ERD system. Membrane manufacturing companies have led the development of RO membranes in South Korea. Woongjin Chemical, a South Korean company, developed a polyamide (PA) RO membrane in the early 1990s. In 2003, Woongjin Chemical ranked third in the world for manufacturing capacity of $\mathrm{RO}$ membrane elements, behind Dow Chemical of the United States and Hydranautics of Japan. However, Woongjin Chemical was acquired by Toray Advanced Materials of Japan in 2014. Now, LG Chem (Seould, Korea) is the only South Korean company manufacturing RO membranes. LG Chem entered the $\mathrm{RO}$ membrane field in 2014 by acquiring an American startup, NanoH2O (Torrance, USA). Currently, Toray (Tokyo, Japan), DuPont (Wilington, USA) (formerly Dow), Hydranautics (Nitto Group Company) (Oceanside, USA), and LG Chem occupy more than $90 \%$ of the PAT RO membranes market [17].

Although RO has become a major technology in the desalination market since 2000, it was only in 2007 that RO technology development actively began in South Korea with the government's R\&D support. The first consortium desalination research project, the SEAHERO R\&D program, started in 2007 with 165 million USD in funding for five years to achieve world-class SWRO technology. Kim et al. introduced the technology concept for this research project in detail [28]. The research was conducted with three technical 
strategies and four core development technologies. The three technical strategies are low energy, low fouling, and large train size (Figure 4a). The four core development technologies consist of (I) future SWRO technology, (II) localization of core parts, (III) large-scale SWRO plant design and construction technology, and (IV) innovative O\&M technology [4].

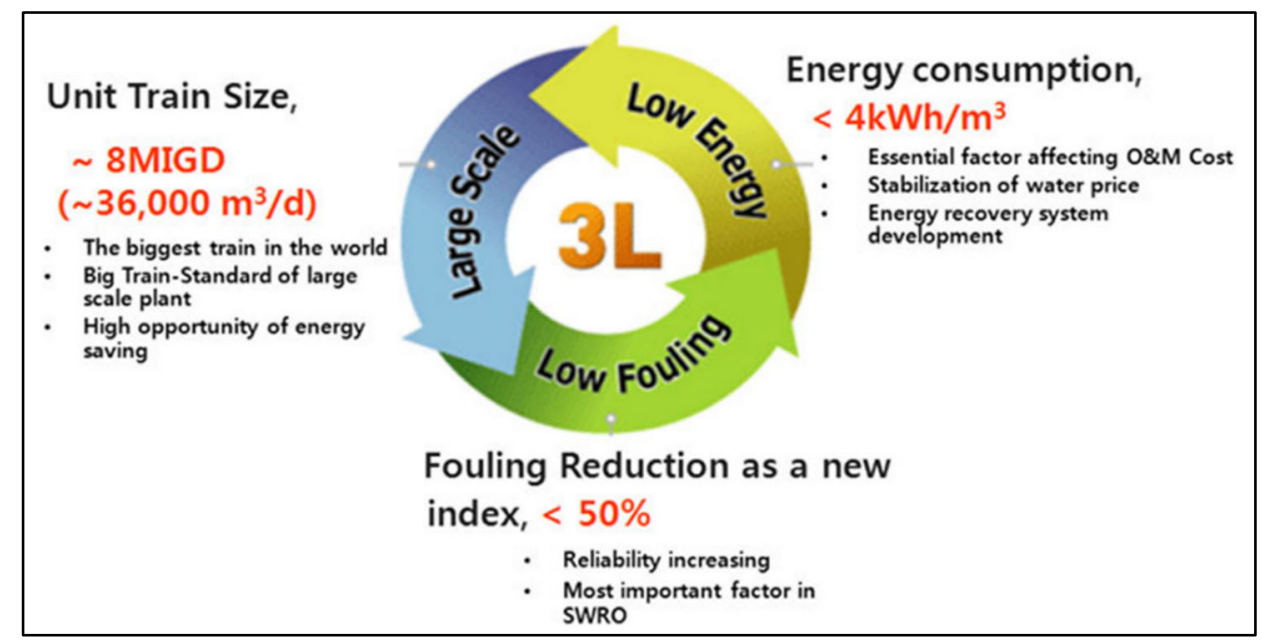

(a)

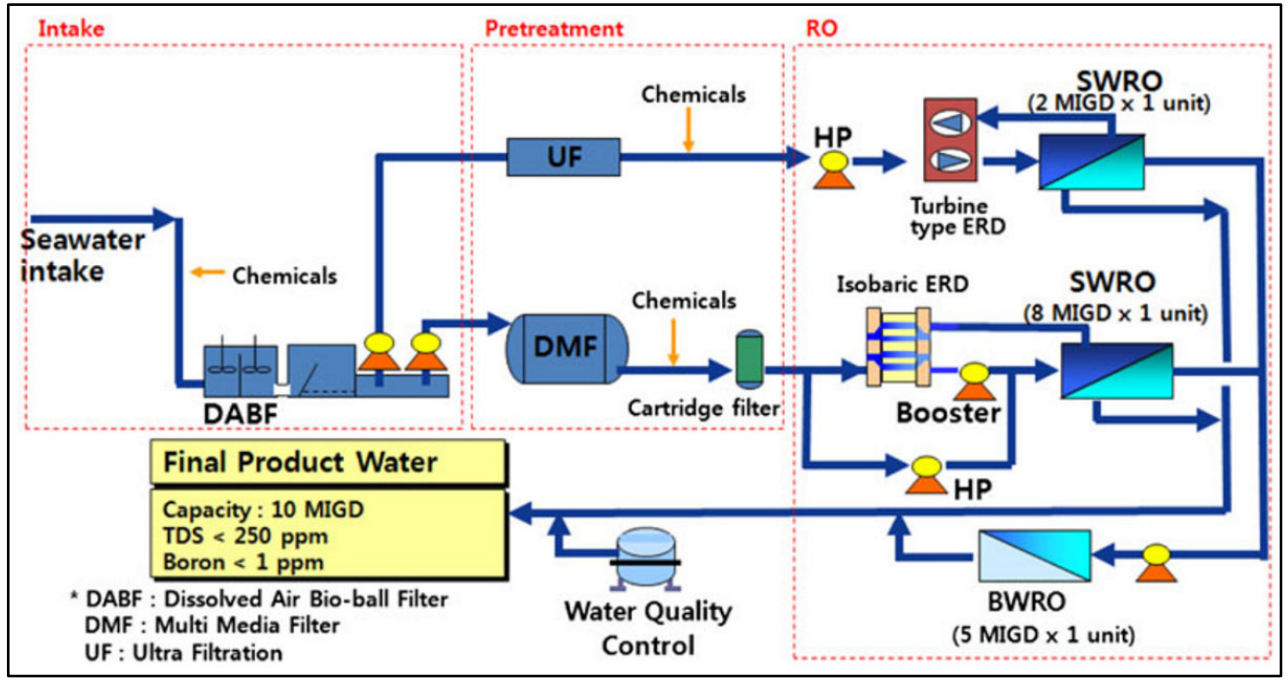

(b)

Figure 4. (a) The three main strategies in the seawater engineering and architecture of high-efficiency reverse osmosis (SEAHERO) research and development program and (b) the flow diagram of the SEAHERO testbed [28].

The South Korean companies Doosan Heavy, Hyosung, and Woongjin Chemical participated in the SEAHERO R\&D program. They were in charge of developing design and engineering technology, a high-pressure pump, and the SWRO membrane, respectively, to achieve localization of major parts of the SWRO process. The most notable achievement of the task was an 8 million imperial gallons per day (MIGD) $\left(\approx 36,000 \mathrm{~m}^{3} /\right.$ day) single SWRO train with dual-media filtration pretreatment. With another 2 MIGD SWRO trains using membrane pretreatment, the total water production capacity was 10 MIGD $\left(\approx 45,000 \mathrm{~m}^{3} /\right.$ day) (Figure $\left.4 \mathrm{~b}\right)$. In addition, a 16-inch SWRO spiral-wound element was developed to reduce the initial investment cost and the operating costs of the SWRO plant. The SEC of the SWRO testbed was estimated to be $3.7 \mathrm{kWh} / \mathrm{m}^{3}$ at the feedwater 
temperature of $10-15^{\circ} \mathrm{C}$. Later, the high-pressure pump developed in this project led to export-worthy performance [29].

\subsection{Forward Osmosis}

Although RO technology has dramatically reduced the SEC of desalination, seawater desalination is still an energy-intensive process. Therefore, advanced desalination technologies have been investigated to reduce energy use further. One of the alternative technologies is FO membrane technology. The $\mathrm{RO}$ membrane process requires hydraulic pressure higher than the osmotic pressure of seawater for water transport, typically 60-70 bar. However, FO technology uses the osmotic pressure as the driving force for water transport; thus, the FO process needs much lower energy for water flux. After introducing the FO process using ammonia-carbon dioxide as the draw solute in 2005, FO has received tremendous attention in academic research and industrial development [30-32]. In the early 2000s, most research has focused on cellulose triacetate (CTA) membranes from Hydration Technologies Inc. However, the commercial CTA membrane showed insufficient performance, such as degradation when exposed to an ammonium bicarbonate draw solution, relatively low water permeability, and salt rejection [33]. Then, research on a specifically tailored PA thin-film composite (TFC) membrane with a porous support layer to minimize internal concentration polarization led to the introduction of a commercial TFC FO membrane, i.e., from Oasys Water in the USA in 2008 [32,34].

Up to now, three consortium-based FO research projects have been conducted in South Korea, as shown in Figure 3. The first and second projects, started in 2009 and 2010, focused on developing FO membranes. As a result, Woongjin Chemical, which participated in the first research project, succeeded in developing a commercial-level spiral-wound element by using its PA TFC RO membrane technology for mass production. The developed FO membrane was applied in FO desalination pilot tests [35,36]. Although the FO pilot testes showed better water flux performance for the developed FO membrane, the research projects faced challenges with applications of the FO process, such as the FO-RO hybrid desalination process using a divalent draw solute.

Water permeating through the FO membranes dilutes the draw solution. Thus, to obtain fresh water as a final product, an additional process for draw solute separation is required. Because of the high energy consumption of the separation process, the theoretical thermodynamic energy required for desalination with $\mathrm{FO}$ is always higher than that without FO [32]. Alternatively, an FO hybrid desalination process using the osmotic dilution concept can be a low-energy process [37-39]. Osmotic dilution means using the osmotic difference between two solutions for water permeation in FO without a draw solution separation process, resulting in a diluted draw solution as a product of the FO process.

The third FO research project that began in 2014 investigated an osmotic dilution FO-RO hybrid process using the world's first pilot-scale plant. Figure 5 shows a schematic diagram of the FO-RO hybrid pilot plant. As shown, the effluent of wastewater treatment is used as the feed solution, and seawater is used as the draw solution. Permeated wastewater dilutes the seawater, decreasing the osmotic pressure of the seawater. Because the applied hydraulic pressure of $\mathrm{RO}$ depends on the osmotic pressure of the seawater, the osmotic dilution of the FO process can reduce energy consumption in the subsequent SWRO process $[14,38]$. The goal of the research was a reduction of the SEC of desalination to $2.5 \mathrm{kWh} / \mathrm{m}^{3}$, and the feasibility was tested in a FO-RO hybrid pilot plant with a capacity of $1000 \mathrm{~m}^{3} /$ day [40]. The pilot plant adapted the plate-and-frame type FO membrane module from Porifera. According to the modeling estimation, the SEC of the FO-RO hybrid desalination plant was $2.16 \mathrm{kWh} / \mathrm{m}^{3}$, which is $24.7 \%$ lower than the SEC of the SWRO process, which is $2.87 \mathrm{kWh} / \mathrm{m}^{3}$ [41]. 


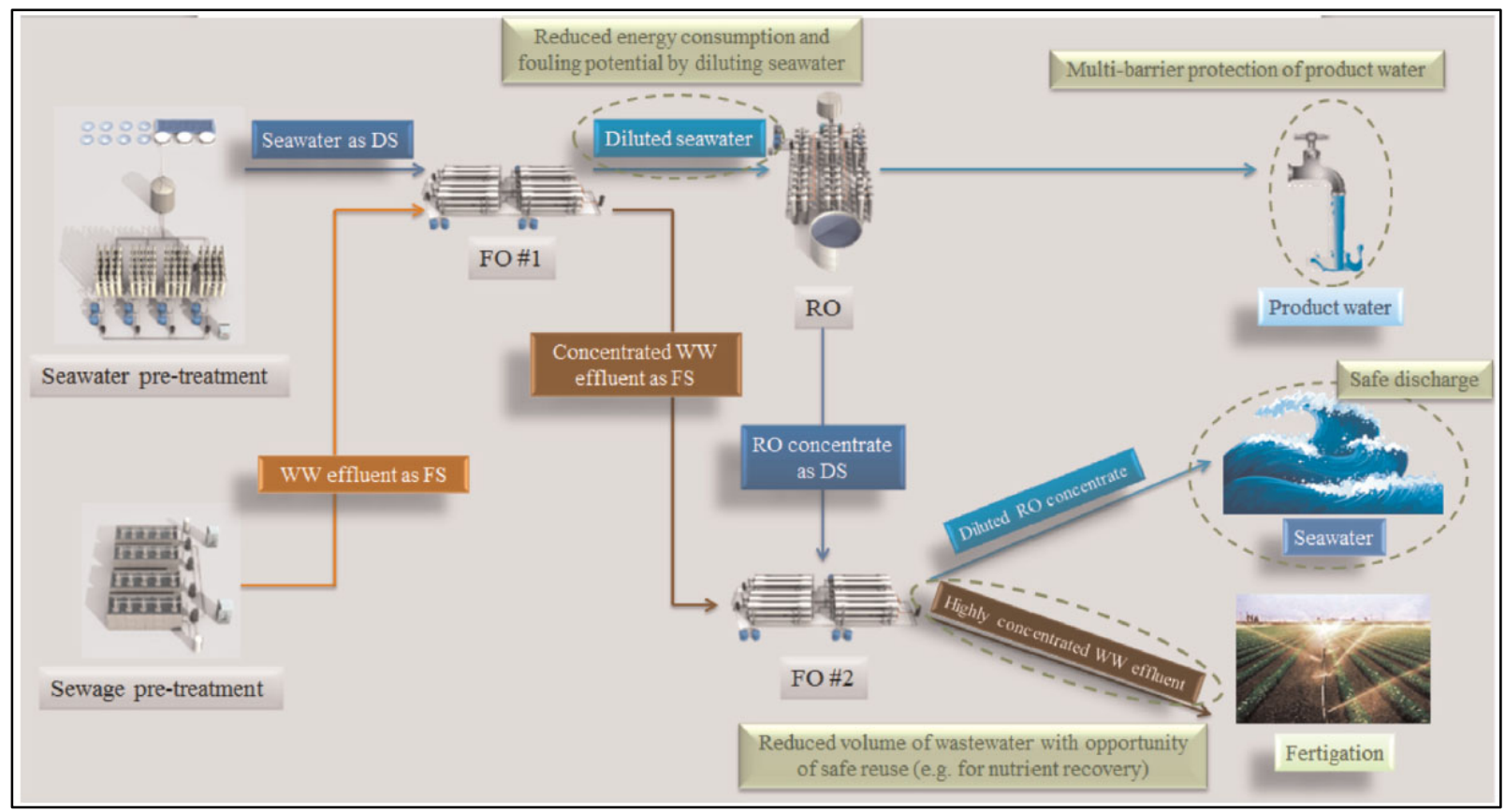

Figure 5. Schematic diagram of the osmotic dilution forward osmosis-reverse osmosis (FO-RO) desalination hybrid pilot plant [37].

\subsection{Pressure-Retarded Osmosis}

Unlike RO or FO processes, which are primarily intended for water treatment by membrane separation, the purpose of the PRO process is to obtain energy from a salinity gradient. PRO uses osmotic water transport, similar to FO, but a hydraulic pressure less than the osmotic pressure difference is applied on the higher concentration solution. The water flux is decreased due to the hydraulic pressure, but energy generation occurs when releasing the hydraulic pressure through a turbine [42]. The theoretical feasibility of PRO was investigated in the 1950s and 1960s, though the development of PRO has been limited due to the complexity of the system and the lack of a suitable membrane [42,43]. The world's first prototype PRO power plant was built by a Norwegian company, Statkraft, in 2009 [42]. Practical electricity generation is still economically challenging because of the insufficient PRO membrane performance. Based on the Statkraft analyses, the minimum power density performance of the membrane should be at least $5 \mathrm{~W} / \mathrm{m}^{2}$ for a commercially viable PRO process [44,45]. Instead of electricity generation, the Mega-ton Water System project in Japan investigated the PRO process to produce hydraulic pressure using a hydraulic Pelton turbine in 2010 [46]. In this project, the PRO pilot plant used $460 \mathrm{~m}^{3} /$ day of SWRO brine as the draw solution and $420 \mathrm{~m}^{3}$ /day of treated wastewater as the feed solution [47]. A hollow-fiber PRO membrane, developed by the Toyobo company, was applied, and the self-reported minimum power density was more than $12 \mathrm{~W} / \mathrm{m}^{2}$, at approximately 30 bar applied hydraulic pressure [46].

The technical challenges of desalination are the relatively high economic costs and environmental concerns caused by brine [14]. To solve these issues, the Global Membrane distillation, Valuable source recovery, PRO (MVP) program, a South Korean governmentfunded project, evaluated the feasibility of RO-PRO and RO-MD hybrid processes for energy recovery and SWRO brine treatment between 2013 and 2018. An RO-PRO hybrid desalination pilot plant with a water production capacity of $240 \mathrm{~m}^{3}$ /day was constructed and operated for more than two years to verify the long-term operation capability [47]. The developed pilot plant used SWRO brine and reclaimed wastewater for the PRO process, and two isobaric pressure exchangers were adopted to use hydraulic pressure without converting it to electricity (Figure 6) [46]. A spiral-wound PRO membrane was developed by Toray Advanced Materials, and GS E\&C was responsible for developing the PRO 
engineering technology. The PRO process dilutes the SWRO brine to mitigate its adverse impact on the marine environment, and the hydraulic pressure from the salinity gradient reduces the SEC of the SWRO process simultaneously. According to the pilot plant test, the SEC was reduced by $19 \%$, and the SWRO brine was diluted to $63 \%$ of its original concentration by applying the PRO process [47]. To improve the SWRO-PRO technology, the development of PRO elements with higher recovery and the optimization of cleaning techniques for PRO membranes are required $[45,47,48]$.

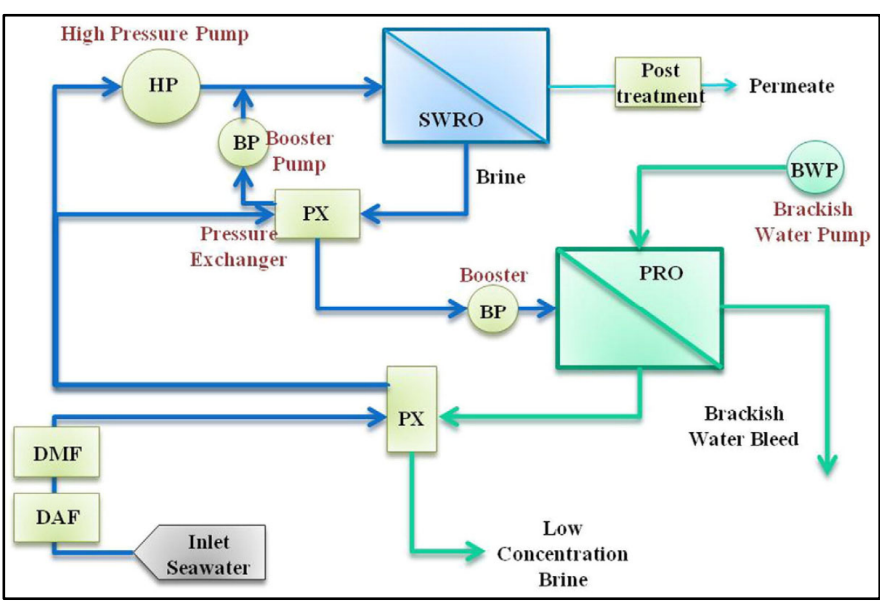

(a)

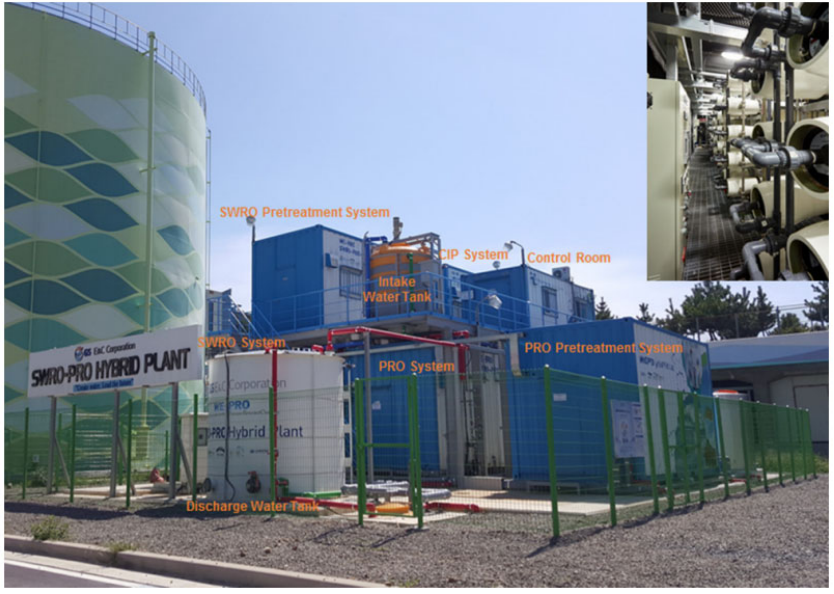

(b)

Figure 6. (a) Schematic diagram of osmotic dilution seawater reverse osmosis-pressure-retarded osmosis (SWRO-PRO) desalination hybrid pilot plant, (b) reverse osmosis (RO)-PRO hybrid desalination pilot with SWRO water production capacity of $240 \mathrm{~m}^{3} /$ day $[46,48]$.

\subsection{Membrane Distillation}

$\mathrm{MD}$ is a thermal, membrane-based desalination process driven by the vapor pressure difference across a hydrophobic, microporous membrane. MD is more energy-intensive than RO. The minimum theoretical energy required for seawater desalination by single-pass direct contact $\mathrm{MD}$ and $\mathrm{RO}$ is $27.6 \mathrm{MJ} / \mathrm{m}^{3}$ and $3.8 \mathrm{MJ} / \mathrm{m}^{3}$, respectively [49]. However, $\mathrm{MD}$ has drawn attention as an emerging technology because the MD process can be operated with low-grade heat sources, including solar energy, geothermal energy, and waste heat energy from industrial production [50]. Moreover, MD can treat high-salinity water that cannot be desalinated by RO.

MD technology for SWRO bine treatment was one of the research themes in the Global MVP project. SWRO brine has total dissolved solids (TDS) concentrations of approximately $70,000 \mathrm{mg} / \mathrm{L}$. Consequently, the hydraulic pressure required to overcome the osmotic pressure of the brine can be greater than the maximum allowable pressure of the SWRO membrane modules and other process equipment [14,51]. The goal of the SWRO-MD research theme was to reduce the volume of brine by $30 \%$ [52]. Previous pilot-scale MD plants used flat or spiral-wound type modules, but the Global MVP project MD pilot plant used hollow-fiber MD modules developed within the research project by Econity Inc. (Yongin, Korea) [52]. Figure 7 shows the process flow diagram of the vacuum MD pilot plant with thermal vapor compression. In the initial stage, an MD pilot plant with a scale of $10 \mathrm{~m}^{3}$ /day was built, and the performance of the MD membrane module and the influence of operating conditions were evaluated [53]. In addition, energy optimization of the MD process was conducted by combining it with renewable solar energy [52]. Later, a larger MD pilot plant with a capacity of $400 \mathrm{~m}^{3}$ /day was designed for SWRO brine treatment [54]. With these development achievements, the next MD research project targeting the desalination market in Middle Eastern countries was launched in 2019. The MD pilot plant will be constructed in a Middle Eastern country and will focus on developing O\&M technologies and the use of renewable energy [22]. 


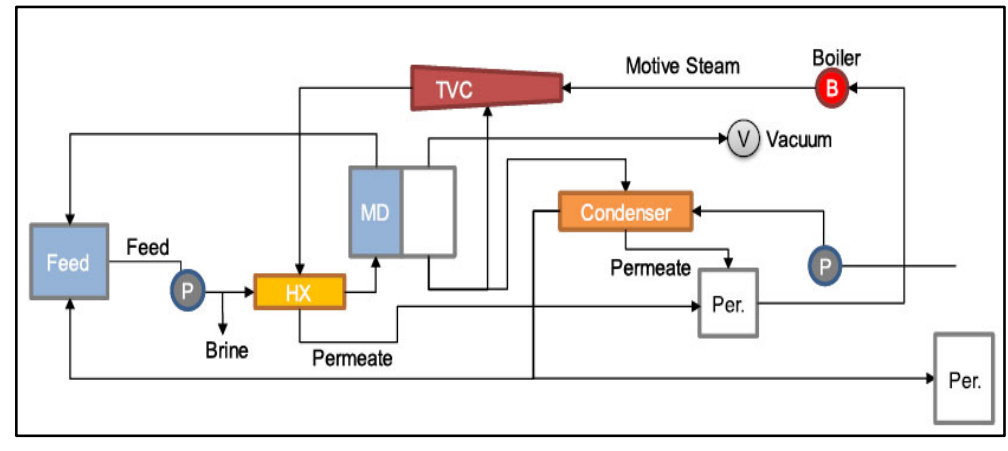

(a)

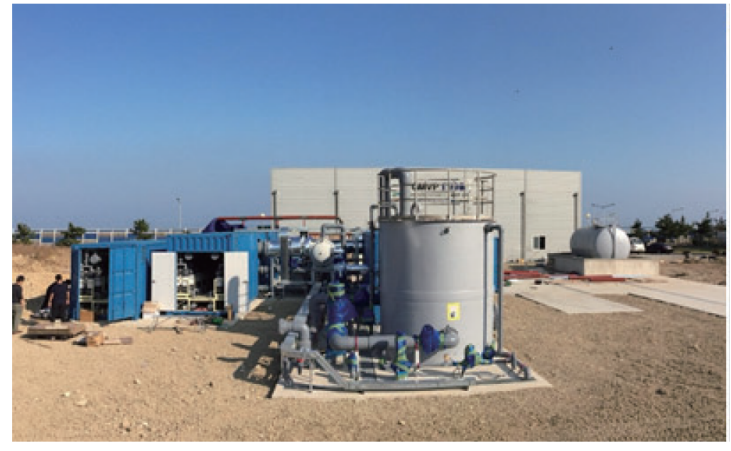

(b)

Figure 7. (a) Schematic diagram of membrane distillation (MD) desalination system, (b) MD desalination pilot plant with a water production capacity of $400 \mathrm{~m}^{3} /$ day $[52,54]$.

\subsection{Capacitive Deionization}

Recently, capacitive deionization (CDI) technology has been extensively studied as an emerging desalination technology. CDI is an electrosorption technology to deionize water by applying an electrical potential difference (usually $<1.2 \mathrm{~V}$ ) over two electrodes, which are often made of porous carbon [55]. The ions are temporarily adsorbed on the surface of the charged electrodes with an external DC energy source, and the adsorbed ions are released back into the solution by short-circuiting or reducing the voltage across the electrodes. In the same manner as a capacitor, energy can be partially recovered during the electrode regeneration step [56-58]. The energy consumption in the CDI process strongly depends on the salt concentration of the feed water because CDI desalinates ions by electrosorption [59]. Thus, it has been suggested that CDI is more energy-efficient than RO for brackish water desalination when the feed salinity is lower than $3.5 \mathrm{~g} / \mathrm{L}$, and the product water salinity is $1 \mathrm{~g} / \mathrm{L}[60]$.

The pilot-scale CDI process has been investigated under themes of the South Korean Optimized RO desalination integrated with the Advanced Energy Saving (KORAE) research project from 2016. The most critical goal of the KORAE project is to develop SWRO technology to reduce energy consumption. SWRO technology is a mature technology, leaving little room for improvement in terms of energy consumption. One of the technical approaches for reducing energy consumption in the project is modifying a second-pass $\mathrm{RO}$ process. A second-pass $\mathrm{RO}$ is used either when the source seawater salinity is higher than $35,000 \mathrm{mg} / \mathrm{L}$ or when stringent final water quality standards must be met for items such as TDS or boron [61]. Boron is one of the most difficult seawater components to remove because boron naturally exists as the undissociated neutral form of boric acid $\left(\mathrm{pK}_{\mathrm{a}} 8.9\right)$ at the typical $\mathrm{pH}$ of seawater (8.1-8.2) [62]. As a result, many SWRO plants have been designed with a two-pass array for boron removal, and the energy consumed in a second-pass RO is typically $0.5 \mathrm{kWh} / \mathrm{m}^{3}$ [63-65]. Therefore, if the CDI process can remove boron or TDS using less than $0.5 \mathrm{kWh} / \mathrm{m}^{3}$, some energy savings can be achieved. Figure 8 shows the conceptual process flow of an SWRO-CDI process replacing the second-pass RO with CDI [55]. A pilot-scale Membrane CDI (MCDI) process with a capacity of $50 \mathrm{~m}^{3} /$ day, developed by Siontech, was examined as an alternative process to the second-pass RO. The CDI process treated the permeate from a single-pass SWRO pilot system $\left(120 \mathrm{~m}^{3} /\right.$ day $)$. The energy consumption of the MCDI process was estimated as less than $0.4 \mathrm{kWh} / \mathrm{m}^{3}$ with an SWRO permeate concentration of less than $500 \mathrm{mg} / \mathrm{L}$ [22]. Moreover, the developed MCDI process can be used to remove not only boron and TDS but also bromide, a precursor of bromated disinfection byproducts [55]. Based on lab-scale tests regarding bromide removal, the energy consumption was estimated to be between $0.05 \mathrm{kWh} / \mathrm{m}^{3}$ and $0.3 \mathrm{kWh} / \mathrm{m}^{3}$, depending on the TDS of the feed water [55]. The energy consumption of CDI can be further optimized by achieving energy recovery from the CDI and using a larger, full-scale CDI process. The KORAE project plans to build an SWRO pilot plant with a capacity of 
$1000 \mathrm{~m}^{3}$ / day in the United Arab Emirates (UAE). Accordingly, the CDI process will also be further examined in terms of energy consumption, removal efficiencies, and O\&M [66].

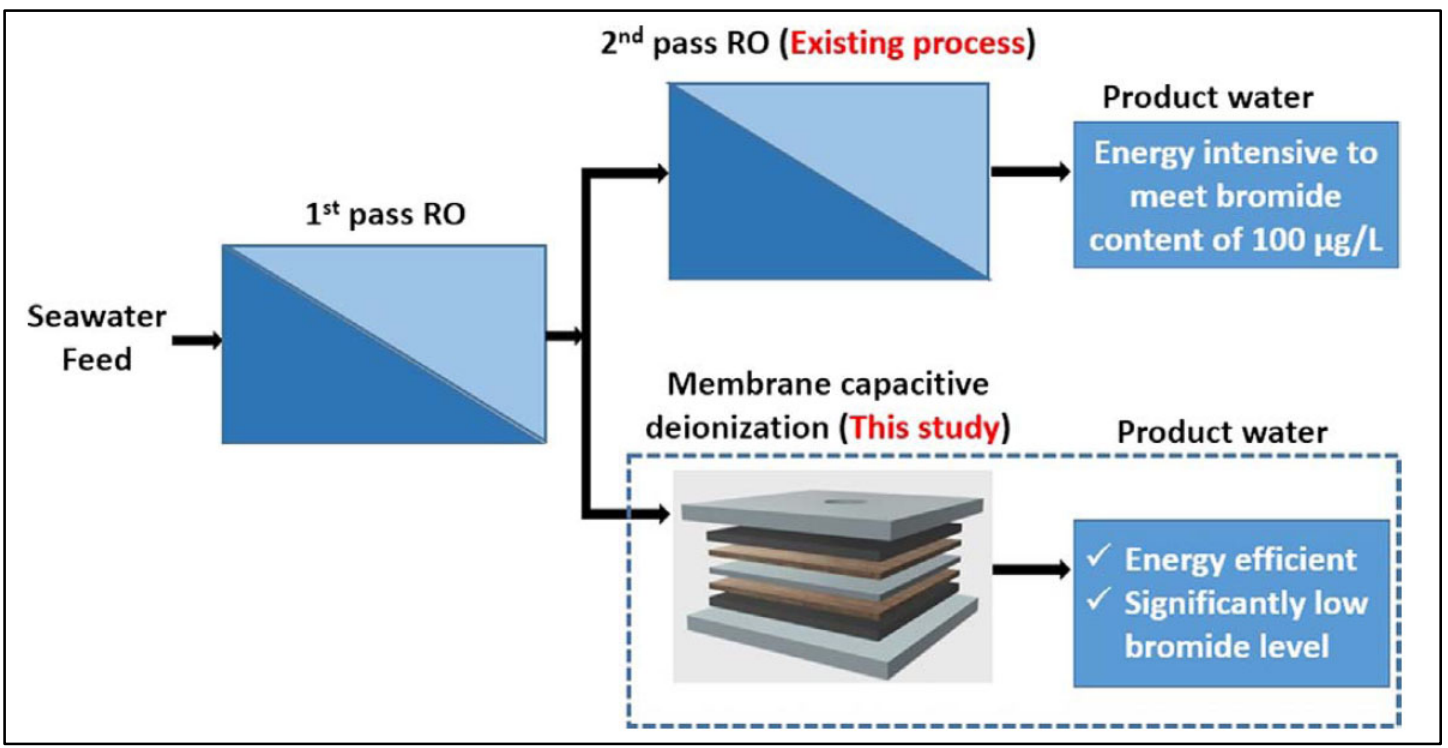

Figure 8. Conceptual diagram of reverse osmosis-capacitive deionization (RO-CDI) process replacing second-pass RO with CDI [55].

\subsection{Renewable-Energy-Powered Desalination}

Energy consumption is a major factor affecting water production costs. In the case of seawater desalination, energy consumption contributes $20-35 \%$ of the total costs of water production, and it can exceed 50\% in extreme conditions for remote plant locations with high unit energy costs [67]. To mitigate this issue, renewable energy use has been suggested as an option to reduce desalination energy requirements. In addition, energy consumption savings can reduce greenhouse gas emissions. The other motivation for developing renewable-energy-powered desalination is recent policies in the Middle East countries regarding the post-oil era [68]. The post-oil projects include renewable-energy-powered desalination. For example, Masdar, the renewable energy company in the UAE, launched a renewable energy desalination pilot program in 2013 to develop advanced technology for sustainable water production [69]. Moreover, the world's largest solar desalination plant recently built in Al Khafji City, Saudi Arabia, with a capacity of 60,000 m³ / day, demonstrates the commitment of the Middle East to the post-oil era.

Renewable-energy-powered desalination has high growth potential, but it is still in the early stages of its application. Currently, installed renewable-energy-powered desalination plants account for only $1 \%$ of global desalination capacity [70,71]. The technically and economically available renewable energy significantly varies by country. The majority of renewable-energy-powered desalination uses wind, solar, or geothermal energy, and the most dominant combination is photovoltaic (PV)-powered RO systems [72]. For small-scale desalination in remote areas, a standalone renewable-energy-powered desalination facility is beneficial considering the high cost of grid connectivity [73].

In South Korea, several renewable-energy-powered desalination facilities have been installed in connection with energy self-sufficient island projects. For instance, a small RO desalination plant with a solar PV energy and energy storage system (ESS) was built on Juk-do island for 70 residents [74]. As a similar energy self-sufficient island project, a PVRO plant was built on Soijak-do island to supply energy and fresh water for 114 residents with a capacity of $200 \mathrm{~m}^{3}$ /day. The plant is equipped with a $100 \mathrm{~kW}$ solar power system, $300 \mathrm{kWh}$ ESS, water quality monitoring and remote-control facilities. Although renewableenergy-powered seawater desalination technology has not been widely applied yet, it will be 
continuously researched to meet the demand in major desalination markets like the Middle East countries and address water shortages on small islands like those in South Korea.

\subsection{Desalination Battery}

Desalination batteries (or seawater batteries) are categorized as an electrochemical desalination process. Desalination battery removes salts by adsorption of dissolved ions, such as electro-deionization and capacitive deionization. A desalination battery has been considered a more appropriate electrochemical desalination technology because of the high salt adsorption capacity (SAC) with high-capacity battery electrode materials [75]. Due to its limited SAC, CDI has been used only for brackish water desalination.

The desalination battery operating process is based on the electrochemical redox reaction. The system consists of the feed or seawater as the electrolyte with $\mathrm{Na}$ - and Clstorage electrodes, which remove salt during the charging process. When charging the system, sodium and chloride ions in the seawater are attracted into the Na-storage electrode and $\mathrm{Cl}$-storage electrode, respectively, resulting in desalination. However, during discharge, ions are released, and the electrodes are regenerated. After the desalination battery was introduced in 2012, it emerged as a next-generation desalination technology [76]. In the past decade, various types of desalination batteries have been developed to enhance desalination capacity, including rocking chair, redox flow, and metal-air desalination batteries [77,78].

Ulsan National Institute of Science and Technology (UNIST) in South Korea is a global leader in desalination battery technology. UNIST developed a battery based on a solid electrolyte. The Korea East-West Power company (KEWP) (Ulsan, Korea) and Korean Electric Power Corporation (KEPCO) (Naju, Korea) are doing research together with UNIST to develop $10 \mathrm{kWh}$ electrical energy storage with desalination batteries. KEWP and KEPCO invested approximately 4,200,000 USD in UNIST during 2016-2019 [79]. Recently they introduced the concept of seawater desalination by rechargeable seawater batteries [80,81]. This type of desalination battery is composed of an open cathode, a sodium super-conducting separator which is the solid electrolyte, and a closed metal-organic anode. In addition, they compared the rechargeable seawater battery desalination system with the RO desalination system.

\section{Conclusions and Prospects}

This review summarizes the current status and trends of desalination technology in South Korea. Similar to global desalination technology trends, the key direction in developing desalination technology in South Korea is reduced energy consumption. In South Korea, significant research on desalination technology has been actively carried out since 2006. As a result, the number of scientific publications on desalination from South Korea ranks fourth in the world after China, the United States, and India. The most studied research topic is RO membrane desalination, and emerging technologies including FO, PRO, $\mathrm{MD}, \mathrm{CDI}$, renewable-energy-powered desalination, and desalination batteries have also been actively studied. It is noteworthy that feasibility studies for the emerging technologies have been carried out on a pilot scale. Table 4 summarizes the major consortium-based desalination research projects and their pilot plants. These studies focused on lowering the energy consumption of desalination and mitigating the environmental impacts of SWRO brine as well. 
Table 4. Summary of representative desalination research programs and their pilot plants in South Korea.

\begin{tabular}{|c|c|c|c|c|}
\hline Research Program & Period & Technology & Pilot Scale ( $\left.\mathrm{m}^{3} / \mathrm{day}\right)$ & $\begin{array}{c}\text { Major Achievements and } \\
\text { Features }\end{array}$ \\
\hline SEAHERO program & 2007-2012 & SWRO & 45,000 & $\begin{array}{ll}\text { - } & \text { SWRO testbed } \\
\text { - } & \text { 16-inch SWRO element } \\
\text { - } & \text { high-pressure RO pump }\end{array}$ \\
\hline $\begin{array}{l}\text { Development of } \\
\text { multi-purpose FO } \\
\text { desalination plant }\end{array}$ & 2009-2014 & $\mathrm{FO}$ & 20 & $\begin{array}{l}\text { - } \quad \text { spiral-wound FO element } \\
\text { - } \quad \text { FO-RO hybrid pilot plant }\end{array}$ \\
\hline Global MVP program & $2013-2018$ & $\begin{array}{l}\mathrm{PRO} \\
\mathrm{MD}\end{array}$ & $\begin{array}{l}240(\mathrm{PRO}) \\
400(\mathrm{MD})\end{array}$ & $\begin{array}{ll}\text { - } & \text { PRO pilot plant with } \\
& \text { pressure exchanger } \\
\text { - } & \text { spiral-wound PRO element } \\
\text { - } & \text { MD pilot plant } \\
\text { - } & \text { MD membrane }\end{array}$ \\
\hline FOHC program & 2014-2019 & $\mathrm{FO}$ & 1000 & $\begin{array}{l}\text { osmotic dilution FO-RO } \\
\text { hybrid pilot plant }\end{array}$ \\
\hline KORAE & $2016-2020$ & $\begin{array}{l}\mathrm{RO} \\
\mathrm{CDI}\end{array}$ & $\begin{array}{c}120 \\
50\end{array}$ & $\begin{array}{ll}\text { - } & \text { high flux and } \\
\text { high-efficiency RO } \\
\text { membrane for single-pass } \\
\text { - } \quad \text { MCDO system } \\
\text { - } \quad \text { SWRO-CDI pilot plant } \\
\text { - } \quad \text { SWRO pilot plant in UAE } \\
\text { (1000 } \mathrm{m}^{3} / \text { day) (plan) }\end{array}$ \\
\hline
\end{tabular}

Research into SWRO desalination technologies has led to the localization of important components of the SWRO process, such as RO membranes and high-pressure pumps. However, there are still ample research needs for the localization of technologies, including high-efficiency ERD, pretreatment, and posttreatment in the SWRO plants.

In South Korea, most SWRO facilities for municipal water are installed on islands with small capacities of less than $500 \mathrm{~m}^{3} /$ day. The need for small desalination facilities on remote small islands will continue to increase in the future, considering the effects of climate change. The primary limitations to further applications of small SWRO facilities are the O\&M of the system and economic feasibility. Automated O\&M units or remote-control systems will be necessary to allow effective management of small SWRO facilities on islands. SWRO plants with renewable energy sources can reduce the economic costs of desalination.

Due to the abundance of fresh water and the low cost of tap water, medium and large SWRO plants have been considered only for industrial water production in the midwestern part of South Korea, which experiences seasonal water scarcity. Desalination can be the best approach to provide stable fresh water for industry and agriculture in these water-scarce areas. The development of SWRO membranes that can meet water quality requirements using single-pass SWRO can also reduce the total cost of SWRO desalination. As the number of reference plants demonstrating performance in terms of water quality and process stability increases, opportunities for other applications such as power and municipal sectors will develop.

Globally, almost half of the desalination capacity is located in the Middle East and North Africa (MENA) region [82]. Accordingly, South Korean companies promote the construction of large-scale desalination plants in overseas markets rather than domestic markets. To increase orders for large-scale desalination plants, it is necessary to develop SWRO engineering technologies and O\&M technologies optimized for the MENA region, i.e., pretreatment technologies for severe algal blooms or accidental oil spills. Pilot-scale studies conducted in the MENA region can provide practical information for developing optimal O\&M technologies to meet local requirements. 
A major environmental concern of desalination is the disposal of the brine produced in the desalination process. Hybrid RO technology processes with emerging technologies such as dilution FO-RO, RO-PRO, and RO-MD not only can resolve the brine issues but also can create new desalination markets. Through pilot-scale research on these technologies, major progress has been made in developing membranes and engineering technologies. However, considering the current technical status and the small market for emerging technologies, continuous support by government policy and additional research and demonstrations are required to improve the performance for commercialization.

Author Contributions: Conceptualization, J.P. and S.L.; investigation, S.L.; writing-original draft preparation, J.P.; writing-review and editing, S.L.; visualization, J.P.; supervision, S.L. All authors have read and agreed to the published version of the manuscript.

Funding: This research was supported by the Basic Science Research Program (No. 2020R1I1 A3069197) and BK21 FOUR (No. 5199990214511) through the National Research Foundation of South Korea (NRF).

Institutional Review Board Statement: Not applicable.

Informed Consent Statement: Not applicable.

Conflicts of Interest: The authors declare no conflict of interest.

\section{References}

1. Mekonnen, M.M.; Hoekstra, A.Y. Sustainability: Four billion people facing severe water scarcity. Sci. Adv. 2016, 2, 1-7. [CrossRef]

2. Boretti, A.; Rosa, L. Reassessing the projections of the World Water Development Report. Npj Clean Water 2019, 2, 15. [CrossRef]

3. Ziolkowska, J.R.; Reyes, R. Impact of socio-economic growth on desalination in the US. J. Environ. Manag. 2016, 167, 15-22. [CrossRef]

4. Hwang, M.-H.; Kim, I.S. Comparative analysis of seawater desalination technology in Korea and overseas. J. Korean Soc. Environ. Eng. 2016, 38, 255-268. [CrossRef]

5. Nam, S.; Chun, K.-W.; Lee, J.U.; Kang, W.S.; Jang, S.-J. Hydrograph separation and flow characteristic analysis for observed rainfall events during flood season in a forested headwater stream. Korean J. Ecol. Environ. 2021, 54, 49-60. [CrossRef]

6. Kim, C.-K.; Yum, S.S.; Oh, S.-N.; Nam, J.-C.; Chang, K.-H. A feasibility study of winter orographic cloud seeding experiments in the korean peninsula. Asia-Pac. J. Atmos. Sci. 2005, 41, 997-1014.

7. Jung, Y.; Shin, J.-Y.; Ahn, H.; Heo, J.-H. The Spatial and temporal structure of extreme rainfall trends in South Korea. Water 2017, 9, 809. [CrossRef]

8. Daesan, First Large Capacity Desalination Plant in South Korea. Available online: https://inima.com/en/comunicacion/detalle/ daesan-primera-planta-desaladora-de-gran-capacidad-en-corea-del-sur (accessed on 11 December 2021).

9. Desalination Faccility in South Korea. Available online: http:/ /www.roplant.or.kr/contents.asp?Depth1=7\&Depth2=5 (accessed on 1 December 2021).

10. Current Status of Seawater Desalination Facility. Available online: http://www.me.go.kr/home/web/policy_data/read.do? pagerOffset=0\&maxPageItems=10\&maxIndexPages=10\&searchKey=title\&searchValue=\%ED $\% 95 \%$ B4 $\%$ EC $\% 88 \% 98 \&$ menuId $=$ 10264\&orgCd\&seq=6565 (accessed on 30 November 2021).

11. Choi, J.-S.; Lee, S.; Kim, J.-M.; Choi, S. Small-scale desalination plants in Korea: Technical challenges. Desalination 2009, 247, 222-232. [CrossRef]

12. Curto, D.; Franzitta, V.; Guercio, A. A Review of the Water Desalination Technologies. Appl. Sci. 2021, 11, 670. [CrossRef]

13. Alkaisi, A.; Mossad, R.; Sharifian-Barforoush, A. A review of the water desalination systems integrated with renewable energy. Energy Procedia 2017, 110, 268-274. [CrossRef]

14. Greenlee, L.F.; Lawler, D.F.; Freeman, B.D.; Marrot, B.; Moulin, P. Reverse osmosis desalination: Water sources, technology, and today's challenges. Water Res. 2009, 43, 2317-2348. [CrossRef]

15. Najid, N.; Fellaou, S.; Kouzbour, S.; Gourich, B.; Ruiz-García, A. Energy and environmental issues of seawater reverse osmosis desalination considering boron rejection: A comprehensive review and a case study of exergy analysis. Process Saf. Environ. Prot. 2021, 156, 373-390. [CrossRef]

16. Kim, J.; Park, K.; Yang, D.R.; Hong, S. A comprehensive review of energy consumption of seawater reverse osmosis desalination plants. Appl. Energy 2019, 254, 113652. [CrossRef]

17. Takabatake, H.; Taniguchi, M.; Kurihara, M. Advanced technologies for stabilization and high performance of seawater RO membrane desalination plants. Membranes 2021, 11, 138. [CrossRef] [PubMed]

18. Abengoa Water Desalination. Available online: https://www.abengoa.com/export/sites/abengoa_corp/resources/pdf/noticias_ y_publicaciones/Presentacion-Desalacion-Agua_en.pdf (accessed on 25 November 2021). 
19. Goh, P.S.; Kang, H.S.; Ismail, A.F.; Hilal, N. The hybridization of thermally-driven desalination processes: The state-of-the-art and opportunities. Desalination 2021, 506, 115002. [CrossRef]

20. GS E\&C to Finalize Acquisition Deal of Spain's Water Treatment Company. Available online: https://pulsenews.co.kr/view.php? year $=2012 \&$ no $=312360$ (accessed on 6 January 2022).

21. GS Inima Environment Wins Desalination Project Worth \$2.1 Billion in Oman. Available online: https://smartwatermagazine. $\mathrm{com} /$ news/smart-water-magazine/gs-inima-environment-wins-desalination-project-worth-21-billion-oman (accessed on 6 January 2022).

22. National Science and Technology Information Service of Korea (NTIS). Available online: https://www.ntis.go.kr/ (accessed on 11 November 2021).

23. Water Desalination Equipment Market Size, Share \& Trends Analysis Report by Technology (Reverse Osmosis (RO), Multi-Stage Flash (MSF) Distillation), by Source, by Application, by Region, and Segment Forecasts, 2020-2028. Available online: https:/ /www grandviewresearch.com/industry-analysis/water-desalination-equipment-market (accessed on 12 December 2021).

24. Zapata-Sierra, A.; Cascajares, M.; Alcayde, A.; Manzano-Agugliaro, F. Worldwide research trends on desalination. Desalination 2021, 519, 115305. [CrossRef]

25. Liang, K.; Ma, Q.; Lu, H.; Fang, H.; Yang, P.; Fan, J. The research and application progress of the isobaric erd technique for swro desalination plant. Desalin. Water Treat. 2020, 202, 14-26. [CrossRef]

26. Woo, Y.C.; Kim, S.H.; Shon, H.K.; Tijing, L.D. Introduction: Membrane Desalination Today, Past, and Future; Elsevier: Amsterdam, The Netherlands, 2018; pp. xxv-xlvi.

27. Kim, S.; Oh, B.S.; Hwang, M.-H.; Hong, S.; Kim, J.H.; Lee, S.; Kim, I.S. An ambitious step to the future desalination technology: SEAHERO R\&D program (2007-2012). Appl. Water Sci. 2011, 1, 11-17.

28. First Domestic Export of High-Pressure Pump for Seawater Desalination Plant. Available online: http://www.ikld.kr/news/ articleView.html?idxno=10687 (accessed on 15 December 2021).

29. Cath, T.Y.; Childress, A.E.; Elimelech, M. Forward osmosis: Principles, applications, and recent developments. J. Membr. Sci. 2006, 281, 70-87. [CrossRef]

30. Zhao, S.; Zou, L.; Tang, C.Y.; Mulcahy, D. Recent developments in forward osmosis: Opportunities and challenges. J. Membr. Sci. 2012, 396, 1-21. [CrossRef]

31. Shaffer, D.L.; Werber, J.R.; Jaramillo, H.; Lin, S.; Elimelech, M. Forward osmosis: Where are we now? Desalination 2015, 356, 271-284. [CrossRef]

32. Yip, N.Y.; Tiraferri, A.; Phillip, W.A.; Schiffman, J.D.; Elimelech, M. High performance thin-film composite forward osmosis membrane. Environ. Sci. Technol. 2010, 44, 3812-3818. [CrossRef] [PubMed]

33. Li, L.; Shi, W.; Yu, S. Research on forward osmosis membrane technology still needs improvement in water recovery and wastewater treatment. Water 2020, 12, 107. [CrossRef]

34. Lee, S. Performance comparison of spiral-wound and plate-and-frame forward osmosis membrane module. Membranes 2020, 10, 318. [CrossRef]

35. Kim, J.; Blandin, G.; Phuntsho, S.; Verliefde, A.; Le-Clech, P.; Shon, H. Practical considerations for operability of an 8" spiral wound forward osmosis module: Hydrodynamics, fouling behaviour and cleaning strategy. Desalination 2017, 404, 249-258. [CrossRef]

36. Chekli, L.; Phuntsho, S.; Kim, J.E.; Kim, J.; Choi, J.Y.; Choi, J.-S.; Kim, S.; Kim, J.H.; Hong, S.; Sohn, J.; et al. A comprehensive review of hybrid forward osmosis systems: Performance, applications and future prospects. J. Membr. Sci. 2016, 497, 430-449. [CrossRef]

37. Hoover, L.A.; Phillip, W.A.; Tiraferri, A.; Yip, N.Y.; Elimelech, M. Forward with osmosis: Emerging applications for greater sustainability. Environ. Sci. Technol. 2011, 45, 9824-9830. [CrossRef]

38. Hancock, N.T.; Black, N.D.; Cath, T.Y. A comparative life cycle assessment of hybrid osmotic dilution desalination and established seawater desalination and wastewater reclamation processes. Water Res. 2012, 46, 1145-1154. [CrossRef]

39. Development of World's First Forward Osmosis-Reverse Osmosis Hybrid Seawater Desalination Technology. Available online: http:/ / www.energydaily.co.kr/news/articleView.html?idxno=103627 (accessed on 18 December 2021).

40. Jeon, J. Evaluation of Energy Consumption and Carbon Emission from a Forward Osmosis and reverse Osmosis Hybrid System for Seawater Desalination; Pukyong National University: Busan, Korea, 2021.

41. Klaysom, C.; Cath, T.Y.; Depuydt, T.; Vankelecom, I.F.J. Forward and pressure retarded osmosis: Potential solutions for global challenges in energy and water supply. Chem. Soc. Rev. 2013, 42, 6959-6989. [CrossRef]

42. Yip, N.Y.; Tiraferri, A.; Phillip, W.A.; Schiffman, J.D.; Hoover, L.A.; Kim, Y.C.; Elimelech, M. Thin-film composite pressure retarded osmosis membranes for sustainable power generation from salinity gradients. Environ. Sci. Technol. 2011, 45, 4360-4369. [CrossRef]

43. Achilli, A.; Childress, A.E. Pressure retarded osmosis: From the vision of Sidney Loeb to the first prototype installation-Review. Desalination 2010, 261, 205-211. [CrossRef]

44. Han, G.; Zhang, S.; Li, X.; Chung, T.-S. Progress in pressure retarded osmosis (PRO) membranes for osmotic power generation. Prog. Polym. Sci. 2015, 51,1-27. [CrossRef]

45. Sarp, S.; Li, Z.; Saththasivam, J. Pressure retarded osmosis (PRO): Past experiences, current developments, and future prospects. Desalination 2016, 389, 2-14. [CrossRef] 
46. Lee, S.; Park, T.-S.; Park, Y.-G.; Lee, W.-I.; Kim, S.-H. Toward scale-up of seawater reverse osmosis (SWRO)—Pressure retarded osmosis (PRO) hybrid system: A case study of a $240 \mathrm{~m}^{3} /$ day pilot plant. Desalination 2020, 491, 114429. [CrossRef]

47. Lee, S.; Kim, Y.C.; Park, S.-J.; Lee, S.-K.; Choi, H.-C. Experiment and modeling for performance of a spiral-wound pressure-retarded osmosis membrane module. Desalin. Water Treat. 2016, 57, 10101-10110. [CrossRef]

48. Lee, S.; Choi, J.; Park, Y.-G.; Shon, H.; Ahn, C.H.; Kim, S.-H. Hybrid desalination processes for beneficial use of reverse osmosis brine: Current status and future prospects. Desalination 2019, 454, 104-111. [CrossRef]

49. Kim, J.; Yeo, I.; Lee, W.; Park, T.; Park, Y. The study of a novel SWRO-PRO hybrid desalination technology. J. Korean Soc. Water Wastewater 2018, 32, 317-324. [CrossRef]

50. Tong, T.; Elimelech, M. The Global rise of zero liquid discharge for wastewater management: Drivers, technologies, and future directions. Environ. Sci. Technol. 2016, 50, 6846-6855. [CrossRef] [PubMed]

51. Drioli, E.; Ali, A.; Macedonio, F. Membrane distillation: Recent developments and perspectives. Desalination 2015, 356, 56-84 [CrossRef]

52. Shaffer, D.L.; Arias Chavez, L.H.; Ben-Sasson, M.; Romero-Vargas Castrillón, S.; Yip, N.Y.; Elimelech, M. Desalination and reuse of high-salinity shale gas produced water: Drivers, technologies, and future directions. Environ. Sci. Technol. 2013, 47, 9569-9583. [CrossRef]

53. Taeshin, P.; Inho, Y.; Choi, J. Introduction of next-generation hybrid seawater desalination technology using membrane distillation (MD) and pressure retarded osmosis (PRO) technology. Water Future 2018, 51, 59-65.

54. Shin, Y.; Choi, J.; Park, Y.; Choi, Y.; Lee, S. Influence of operation conditions on the performance of pilot-scale vacuum membrane distillation (VMD). Desalin. Water Treat. 2017, 97, 1-7. [CrossRef]

55. Dorji, P.; Choi, J.; Kim, D.I.; Phuntsho, S.; Hong, S.; Shon, H.K. Membrane capacitive deionisation as an alternative to the 2nd pass for seawater reverse osmosis desalination plant for bromide removal. Desalination 2018, 433, 113-119. [CrossRef]

56. Kang, J.; Kim, T.; Shin, H.; Lee, J.; Ha, J.-I.; Yoon, J. Direct energy recovery system for membrane capacitive deionization. Desalination 2016, 398, 144-150. [CrossRef]

57. Tan, C.; He, C.; Fletcher, J.; Waite, T.D. Energy recovery in pilot scale membrane CDI treatment of brackish waters. Water Res. 2020, 168, 115146. [CrossRef] [PubMed]

58. Omosebi, A.; Li, Z.; Holubowitch, N.; Gao, X.; Landon, J.; Cramer, A.; Liu, K. Energy recovery in capacitive deionization systems with inverted operation characteristics. Environ. Sci. Water Res. Technol. 2020, 6, 321-330. [CrossRef]

59. Kim, N.; Lee, J.; Kim, S.; Hong, S.P.; Lee, C.; Yoon, J.; Kim, C. Short review of multichannel membrane capacitive deionization: Principle, current status, and future prospect. Appl. Sci. 2020, 10, 683. [CrossRef]

60. Qin, M.; Deshmukh, A.; Epsztein, R.; Patel, S.K.; Owoseni, O.M.; Walker, W.S.; Elimelech, M. Comparison of energy consumption in desalination by capacitive deionization and reverse osmosis. Desalination 2019, 455, 100-114. [CrossRef]

61. Rybar, S.; Boda, R.; Bartels, C. Split partial second pass design for SWRO plants. Desalin. Water Treat. 2010, 13, 186-194. [CrossRef]

62. Segal, H.; Birnhack, L.; Nir, O.; Lahav, O. Intensification and energy minimization of seawater reverse osmosis desalination through high-pH operation: Temperature dependency and second pass implications. Chem. Eng. Process. 2018, 131, 84-91. [CrossRef]

63. McGovern, R.K.; Lienhard, V.J.H. On the potential of forward osmosis to energetically outperform reverse osmosis desalination J. Membr. Sci. 2014, 469, 245-250. [CrossRef]

64. Glueckstern, P.; Priel, M. Optimization of boron removal in old and new SWRO systems. Desalination 2003, 156, 219-228. [CrossRef]

65. Stein, S.; Sivan, O.; Yechieli, Y.; Kasher, R.; Nir, O. An advantage for desalination of coastal saline groundwater over seawater in view of boron removal requirements. Environ. Sci. Water Res. Technol. 2021, 7, 2241-2254. [CrossRef]

66. Hong, S.; Hwang, M.-H.; Lim, S.k.; Chu, K.H.; Kim, N.; Park, K.; Kim, J. Development of the low energy seawater desalination technology optimized for the Middle East. J. Korean Soc. Civ. Eng. 2019, 62, 26-37.

67. Voutchkov, N. Desalination Engineering: Planning and Design; McGraw Hill Professional: New York, NY, USA, 2012.

68. Sarant, L. The Middle East: An end to oil dependency. Nature 2016, 537, S6-S7. [CrossRef] [PubMed]

69. Masdar's Renewable Energy Desalination Pilot Programme Finds Solar Energy-Powered Desalination to be CommerciallyViable. Available online: https:/ / news.masdar.ae/en/news/2019/02/19/10/00/masdars-renewable-energy-desalination-pilotprogramme-finds-solar-energy-powered-desalination (accessed on 12 November 2021).

70. Ghaffour, N.; Mujtaba, I.M. Desalination using renewable energy. Desalination 2018, 435, 1-2. [CrossRef]

71. Ahmadi, E.; McLellan, B.; Mohammadi-Ivatloo, B.; Tezuka, T. The role of renewable energy resources in sustainability of water desalination as a potential freshwater source: An updated review. Sustainability 2020, 12, 5233. [CrossRef]

72. Bundschuh, J.; Kaczmarczyk, M.; Ghaffour, N.; Tomaszewska, B. State-of-the-art of renewable energy sources used in water desalination: Present and future prospects. Desalination 2021, 508, 115035. [CrossRef]

73. El-Hady, B.; Kashyout, A.; Hassan, A.; Hassan, G.; El-Banna Fath, H.; El-Wahab Kassem, A.; Elshimy, H.; Ranjanvepa; Shaheed, M.H. Hybrid renewable energy/hybrid desalination potentials for remote areas: Selected cases studied in Egypt. RSC Adv. 2021, 11, 13201-13219. [CrossRef]

74. Yang, S.H.; Jung, S.H.; Yang, D.K.; Kim, M.K.; Oh, S.J. A case study of automated energy independence island for Juk-do. In Proceedings of the Korean Institue of Power Elecronics, Hoengseong, Korea, 3 July 2018; pp. 171-173. 
75. Park, S.; Ligaray, M.; Kim, Y.; Chon, K.; Son, M.; Cho, K.H. Investigating the influence of catholyte salinity on seawater battery desalination. Desalination 2021, 506, 115018. [CrossRef]

76. Ahmed, F.E.; Khalil, A.; Hilal, N. Emerging desalination technologies: Current status, challenges and future trends. Desalination 2021, 517, 115183. [CrossRef]

77. Xu, D.; Wang, W.; Zhu, M.; Li, C. Recent advances in desalination battery: An initial review. ACS Appl. Mater. Interfaces 2020, 12, 57671-57685. [CrossRef]

78. Wang, J.; Dai, J.; Jiang, Z.; Chu, B.; Chen, F. Recent progress and prospect of flow-electrode electrochemical desalination system. Desalination 2021, 504, 114964. [CrossRef]

79. Korea East-West Power Company (KEWP) and Korean Electric Power Corporation (KEPCO) Invest 5 Billion Won in UNIST Seawater Battery Development. Available online: https://news.mt.co.kr/mtview.php?no=2017013109260876853 (accessed on 12 December 2021).

80. Son, M.; Park, S.; Kim, N.; Angeles, A.T.; Kim, Y.; Cho, K.H. Simultaneous energy storage and seawater desalination using rechargeable seawater battery: Feasibility and future directions. Adv. Sci. 2021, 8, 2101289. [CrossRef] [PubMed]

81. Hwang, S.M.; Park, J.-S.; Kim, Y.; Go, W.; Han, J.; Kim, Y.; Kim, Y. Rechargeable seawater batteries-From concept to applications. Adv. Mater. 2019, 31, 1804936. [CrossRef]

82. Jones, E.; Qadir, M.; van Vliet, M.T.H.; Smakhtin, V.; Kang, S.-M. The state of desalination and brine production: A global outlook. Sci. Total Environ. 2019, 657, 1343-1356. [CrossRef] 